\title{
Društveni položaj žena u Republici Hrvatskoj: žena i obitelj (1999. - 2016.)
}

\author{
SMILJANA LEINERT NOVOSEL \\ Fakultet političkih znanosti, Sveučilište u Zagrebu
}

\begin{abstract}
Sažetak
Longitudinalno istraživanje percepcije mladih, obrazovanih ispitanika o promjenama uloga žena i muškaraca u Hrvatskoj (1999. - 2016.) ukazuje na visoki stupanj postignute egalitarnosti u sferi javnosti, "izvan doma" (kontrolirano kroz vrste zanimanja i karakter uloga). U privatnoj sferi, "u domu”, postoji stagnacija, čak pogoršanje ženinog položaja u obitelji - nalazi govore o "vraćanju" patrijarhalnih modela rodnih uloga, posebice onih vezanih uz odgoj djece i brigu za starije članove te kućanske obaveze. Očekuje se da se žene više nego prije, iako rade, brinu oko odgoja djece, vode djecu liječniku, odlaze na roditeljske sastanke, brinu za starije, dok im se u kućanskim poslovima postupno pridružuju i muškarci; oni manje participiraju u aktivnostima oko djece (ranije je bio pozitivan trend), što muškarcima povećava šanse u vezi sa zaposlenošću i profesionalnim razvojem. Tome u prilog svjedoči i različita struktura korištenja slobodnog vremena - žene ga još uvijek dominantno posvećuju obitelji, ponešto brizi za osobni izgled, a muškarci sebi (informiranje, napredovanje). Iako mladima ideal ostaje moderna obitelj i egalitarni odnosi na svim razinama, praksa se zasad od toga udaljava u odnosu na 1999. Nastavak kumulacije uloga za žene, onih modernih i tradicionalnih, bez preraspodjele, dovodi do pitanja jačaju li tradicionalna shvaćanja ili se radi o "tradicionalnosti iz nužde" kao odgovoru na prepuštanje odgovornosti za organizaciju obiteljskog života isključivo pojedincima.
\end{abstract}

Ključne riječi: rodna ravnopravnost, studenti, uloge žena i muškaraca, obitelj, društvo

\section{Uvod}

Godine 2011. objavljeni su rezultati istraživanja te tiskana knjiga Rodna ravnopravnost $i$ diskriminacija u Hrvatskoj. Istraživanje "Percepcija, iskustva i stavovi o rodnoj diskriminaciji u RH” (Kamenov i Galić, 2011) koja je trebala odgovoriti na 
pitanja postoji li danas rodna diskriminacija u Republici Hrvatskoj, prepoznaju li je naši ispitanici, u kojim je segmentima društva prisutna, kroz kakve oblike djeluje te kako ju je moguće objasniti. Jedan od interesantnijih nalaza bio je onaj vezan uz usporedbu područja u kojima je rodna diskriminacija najviše prisutna. Pokazalo se, naime, da je ljudi najčešće prepoznaju u obiteljskom krugu, zatim na radnom mjestu, dok je, možda neočekivano, najmanje prisutna u sferi politike. "Ključni nalaz vezan uz iskustva diskriminacije u politici dobiva pun smisao pri usporedbi odgovora ispitanika za iskustva u različitim područjima života: nalaz za politiku daleko je najniži $(M=0,29)$, uz samo $1 \%$ iskustva, što je devet puta manje od nalaza vezanog uz posao i obrazovanje, do gotovo dvadeset puta manje od nalaza za područje obitelji” (Leinert Novosel, 2011: 203).

Promjena odnosa u obitelji, vezana prije svega uz drugačije uloge žene i muškarca u njoj, posljednjih su desetljeća u najvećoj mjeri povod za prepoznavanje spolne diskriminacije, što potvrđuju i brojna istraživanja. One su istodobno i pokazatelj ne samo promjena u sferi privatnosti već i širih društvenih promjena koje se reflektiraju kroz odnose među spolovima. Postaje li hrvatsko društvo s tim u vezi ravnopravnije, modernije, ili praksa pokazuje nešto drugo?

U knjizi Žena na pragu 21. stoljeća - između majčinstva i profesije, objavljenoj 1999. godine, prezentirala sam rezultate istraživanja uloga žena i muškaraca u hrvatskom društvu te obiteljima ispitanika na uzorku ${ }^{1}$ tadašnjih studenata zagrebačkog sveučilišta. Smatrala sam to interesantnim s obzirom na važnost dopiranja do spoznaja o tome kako nove, obrazovane generacije koje će sukreirati budućnost društva "vide" uloge žena i muškaraca u društvu općenito, kako vide uloge svojih roditelja, kako planiraju svoje te kako će, po njihovom mišljenju, ti odnosi izgledati u budućnosti. Dakle, jesu li skloniji tradicionalnijem tj. patrijarhalnijem stilu života (sličnom onome unazad stotinjak godina) ili modernijem (s progresivnijom, ali i dalje ograničenom redistribucijom uloga) ili kombinaciji jednog i drugog.

Ključni nalazi iz 1999. godine ukazivali su na to da su se studenti priklanjali konceptu uloge žena u društvu s obzirom na dva presudna momenta: tip socijalizacije u obitelji te na drugom mjestu u to vrijeme - utjecaj medija. Iako se njihov odgoj najvećim dijelom odvijao u razdoblju socijalizma (s obzirom na tadašnju dob ispitanika), oni su se u velikoj većini izjašnjavali kao vjernici (82\%). Promjene k modernijem konceptu bile su ipak zamjetne glede činjenice da su im majke većinom bile, odnosno jesu zaposlene ( $89 \%$ žene, $84 \%$ muškarci), što je uvjetovalo da su roditelji najčešće zajednički donosili odluke glede obitelji (66\% žene, 64\% muš-

${ }^{1}$ Prigodni uzorak od petstotinjak studenata druge i treće godine studija (fakulteti iz različitih znanstvenih područja, Sveučilište u Zagrebu). 
karci) te da su morali modernije organizirati obiteljski život. To je svjedočilo o ravnomjernijoj podjeli zadaća u obitelji između žene i muškarca.

Zajedničke zadaće ovdje su bile: zarađivanje za život, briga oko djece i odgoja, briga za financijske poslove, plaćanje računa i sl., briga za starije članove, organizacija obiteljskih proslava i bavljenje sportom te posebno znakovito - usavršavanje u profesiji. Tipične majčine uloge ostale su one vezane uz kućanske poslove: kuhanje, pranje, glačanje te odlazak dječjem liječniku ili na školske sastanke. Pretežno očeva zadaća ostala je samo politička aktivnost. Posljedica je bila u različitoj količini i strukturi korištenja slobodnog vremena majke i oca, pa je tako majka u 90\% slučajeva slobodno vrijeme koristila radeći za obitelj, dok ga je tek u $2 \%$ slučajeva koristila za sebe (zabava, odmor). S obzirom na spomenuto, subjektivni doživljaj žena prema kojemu je njima u životu mnogo teže negoli muškarcima (65\% žena, $29 \%$ muškaraca) svjedočio je o mjeri u kojoj (ni)su nastupile istinske promjene $\mathrm{u}$ obiteljskim ulogama. Postojeća raspodjela odredila je i vrste zadaća namijenjene djeci (našim studentima): studentice su prvenstveno obavljale kućanske poslove, pa tek onda i muške i ženske, a studenti prvenstveno muške te potom zajedničke.

Ti su nalazi ukazali na značaj uloge roditeljskog odgoja na odabir tradicionalnije, odnosno modernije društvene opcije u budućnosti, a sami su studenti priznali kako je njihovo shvaćanje položaja žena u društvu prvenstveno posljedica roditeljskog utjecaja (45\% žene, $46 \%$ muškarci), a tek potom medija (32\% žene, $31 \%$ muškarci). Studenti su ponašanje vlasti i njenu brigu za žene ocijenili osrednjom ili slabom (73\% žene, 59\% muškarci), uz napomenu da bi svakako trebalo činiti više (94\% žene, $60 \%$ muškarci). Kritičnost je pokazivala korelaciju s modernijim shvaćanjem društvenog položaja žene, što se moglo iščitati kroz težnje za jednakim zapošljavanjem, bez obzira na spol, jednakim napredovanjem na radnom mjestu te podrškom ženi na najvišim političkim pozicijama. Očigledno su se mladi visokoobrazovani ljudi dominantno sve više usmjeravali, prema ondašnjim nalazima, modernijim vrijednostima. Potvrda za to stigla je i kroz prognozu o odnosima $u$ vlastitoj obitelji u budućnosti te doživljaju žene kao nadređene u poslovnoj ili čak političkoj hijerarhiji. Modernost stavova mladih ogledala se u planiranju manjeg broja djece - najčešće dvoje (52\% žene, $45 \%$ muškarci), u zajedničkoj brizi za njih (43\% žene, $33 \%$ muškarci), uz potporu zapošljavanju supruge i njenom usavršavanju (64\% žene, 33\% muškarci).

Analogno, raspodjela obiteljskih zadaća planirala se u smjeru većeg stupnja egalitarnosti među partnerima, pa i najtvrdokornije rodno "uvjetovane" uloge, ona ženska - odgoj i briga oko djece, te muška - sudjelovanje u političkim aktivnostima, u perspektivi su trebale postati zajedničkima (75\% žene, $73 \%$ muškarci te $71 \%$ žene i $58 \%$ muškarci). Interesantno je ovdje izdvojiti jednu iznimku koja se s 
vremenom pokazala dosta tvrdokornom: kućanski poslovi ostajali su i u perspektivi rodno određeni (o čemu su u jednakoj mjeri "svjedočili" svaki drugi student $i$ studentica). Pokazalo se, međutim, da konkretno mladi uočavaju kako su neke zadaće više komplementarne, dok se druge isključuju. Pokazalo se da onaj tko zarađuje, usavršava se i napreduje u profesiji manje sudjeluje u odgoju i brizi za djecu $(r=-.49)$, odlasku dječjem liječniku $(r=-.42)$, ili na roditeljske sastanke $(r=-.43)$. Poseban test modernizma bili su stavovi glede poželjnosti žena na rukovodećim pozicijama na radnom mjestu i onih o ženi na čelu države.

Spomenuti su nalazi bili u skladu sa zaključcima ostalih istraživanja vezanih uz dominantne društvene promjene u RH prvih tranzicijskih godina. Naime, istraživanja su tada ukazivala, na uzorku četiriju velikih gradova, na različita shvaćanja položaja i uloge žena u društvu određenih segmenata društva (Leinert Novosel, 1999). Pokazala se razlika između pobornika tradicionalnih društvenih vrijednosti, njih oko jedne trećine, nasuprot brojčano gotovo dvostruko brojnijoj skupini "modernista". Podsjetimo se da su "tradicionalisti" izjavljivali da je ženama mjesto u kući gdje se trebaju brinuti o kućanstvu i odgoju djece, da bi za položaj žena u društvu morao biti presudan utjecaj crkve, da žene uopće nisu rođene za politiku te da im ne treba ostavljati slobodu odlučivanja o pobačaju. Takve tradicionalne stavove bilo je moguće svesti na četiri glavna segmenta: podjelu uloga među spolovima $u$ obitelji i šire u društvu, poštivanje autoriteta, vezivanje žena isključivo za privatnu sferu života te podređivanje individualne slobode interesima kolektiva. Obrazovanje je više no zaposlenost diferenciralo žene i muškarce koji su pristajali uz te društvene vrijednosti. Za razliku od njih, "modernisti” su se izjašnjavali u visokom postotku za uklanjanje podjele uloga u obitelji i društvu, ukidanje vrhovnog autoriteta i uspostavu partnerskih odnosa, ženino sudjelovanje i u privatnoj i u javnoj sferi te osobni odabir u planiranju obiteljskog života. I ovdje su obrazovanje, čak i zaposlenost, ukazivali na vezu s pristajanjem uz te vrijednosti. Rezultati tih istraživanja su, kod urbane populacije, upućivali na većinsku zastupljenost onih koji podržavaju modernije vrijednosti.

Od brojnih istraživanja srodnih tema posljednjih desetak godina za svrhe ovog rada interesantno je izdvojiti nekoliko nalaza. Što se tiče usporedbe novih i starih uloga žena i muškaraca u suvremenoj Europi, prema EVS-u iz 1999. godine, Črpić, Bišćan i Aračić (2005) ističu kako 1/5 Europljana drži da "majka koja radi može uspostaviti jednako topao odnos s djetetom kao majka koja ne radi", dok s druge strane više od 50\% njih smatra da će "predškolsko dijete vjerojatno trpjeti ako njegova majka radi”. Isto tako je za većinu Europljana/ki (više od 60\%) najbolji način da žena postigne neovisnost njezino zaposlenje. U istom je istraživanju faktorska analiza pokazala dvije stabilne dimenzije - "tradicionalni odnos prema ulozi žene" i "ekonomska uloga žene" (modernizacijska dimenzija). S obzirom na to da društvo 
još ne shvaća posljedice kumulacije uloga žena - uz ekonomski doprinos i tradicionalne obiteljske zadaće te prateću "mušku rezistenciju", kako zaključuju Črpić, Bišćan i Aračić (2005), naše je društvo moguće prepoznati kao umjereno tradicionalno, slično talijanskome ili poljskome, "s kojima ih povezuje katolička većina te pripadnost srednjoeuropskom i mediteranskom krugu” (Galić, 2011: 25).

Istraživanje Ivane Jugović i Željke Kamenov o promjenama u roditeljskim ulogama u Hrvatskoj (Kamenov i Jugović, 2011) pokazalo je da do promjena dolazi postepeno i u kvantitativnom i u sadržajnom pogledu. Prema nalazu iz 2007. godine (Kamenov i sur., 2007), podjela poslova među partnerima, kao što su briga za kućanske poslove i djecu te zajedničko odlučivanje, u izrazitoj je vezi s osjećajem zadovoljstva $\mathrm{u}$ braku, posebice kod žena. Ti podaci ukazuju na trend promjena $u$ pravcu modernijih shvaćanja obiteljskih odnosa, ali detektiraju i mjesta na kojima se pomaci rijetko uočavaju - kućanski i odgojni zadaci te briga za mlađe i starije članove obitelji. Konkretno, čak i kada je zaposlena, žena radi većinu kućanskih poslova, iako, logično, manje od nezaposlene, odnosno, kako navode Jugović i Kamenov: "Istraživanja pokazuju da muževi zaposlenih žena nisu bili uključeni u brigu o djeci i kućanske poslove više od muževa nezaposlenih žena" (Kamenov i Jugović, 2011: 35).

Ostala istraživanja u spomenutom razdoblju pokazuju slične nalaze, one o dvostrukoj, čak trostrukoj opterećenosti žena - na poslu, u kućanstvu i u vezi s dodatnom zaradom (Leinert Novosel, 1999; 2003; 2011), o dosadnim, repetitivnim poslovima u kućanstvu koji su "tipični” za žene (Tomić-Koludrović i Kunac, 2000), a dokaz da je tome tako nalazimo i u istraživanju (Kamenov i sur., 2007) gdje se $87 \%$ ispitanih parova složilo da glavninu kućanskih poslova i aktivnosti vezanih uz djecu te brigu za starije preuzimaju upravo žene. Iako se radi o različitim tipovima istraživanja, odnosno uzoraka, bit će interesantno spomenute nalaze staviti u kontekst najnovijih odgovora studenata iz ponovljenog istraživanja 2016. godine, a posebno njihovog "viđenja" eventualnih promjena u pravcu očekivanih modernijih shvaćanja u odnosima žena i muškaraca. Što se zbivalo s ulogama u javnom, a što u privatnom životu te kakve su prognoze za budućnost?

\section{Istraživanje studentske populacije 2016.}

Istraživanje ${ }^{2}$ je, naime, ponovljeno s namjerom da se pokaže kakvo je stanje u obiteljima današnjih studenata u vezi s tipičnim zadaćama u obitelji, jesu li nastupile očekivane promjene tijekom godina - u pravcu egalitarnije podjele uloga, $u$ čemu

2 Radi se o longitudinalnom istraživanju (1999. - 2016.) na uzorku studentske populacije, petstotinjak ispitanika zagrebačkog sveučilišta; podaci prikupljeni početkom 2016. godine primjenom identičnog mjernog instrumenta. 
se one očituju te kako ih možemo interpretirati. Ti podaci indirektno odgovaraju o smjeru društvenog razvoja, ali i o stupnju istinske rodne ravnopravnosti u društvu.

S obzirom na dosadašnje nalaze moguće je postaviti hipotezu prema kojoj mlada, obrazovana (studentska) populacija danas u društvu općenito prepoznaje modernije vrijednosti, odnosno, u konkretnom slučaju, prepoznaje egalitarnost uloga žena i muškaraca ponajprije "izvan doma". Istodobno, u nešto manjoj mjeri percipiraju ih egalitarnima u sferi privatnosti - "u domu”. Ova hipoteza pretpostavlja da se egalitarnost "izvan doma" testira kroz uključenost žena i muškaraca u sve vrste zanimanja (odgoj i obrazovanje, administrativno-tajničke poslove, sudstvo, medicinu, znanost, direktorsko-menadžerska, IT zanimanja te politiku) te kroz podjednaku uključenost u uloge izvan doma - usavršavanje u profesiji, zaradu za život, bavljenje sportom i rekreacijom te politiku. "U domu" se uloge promatraju s obzirom na uključenost žena i muškaraca u kućanske poslove, odgoj djece, odlazak dječjem liječniku i na roditeljske sastanke te brigu za starije članove. Različitost u participaciji odražava se i na količinu te strukturu slobodnog vremena žena i muškaraca.

Tip socijalizacije studenata (zaposlenost majke, zajedničko odlučivanje majke i oca, egalitarnost uloga majki i očeva u domu i izvan njega te egalitarne pozicije djece) ukazuje na karakter odnosa u vlastitoj obitelji u budućnosti. Ispitanici će u budućnosti svoje obitelji organizirati modernije, odnosno njihove uloge u obitelji i izvan nje bit će egalitarnije. Viši stupanj egalitarnosti prisutan je i u prognoziranju uloga žena i muškaraca u društvu u budućnosti (za dvadeset godina).

\section{Uloge žena i muškaraca u društvu}

\section{Uloge žena i muškaraca "izvan doma"}

Ranije tipično žensko zanimanje - odgoj i obrazovanje, danas se takvim percipira dvostruko ili trostruko rjeđe negoli 1999. godine (s 97\% Ž i 93\% M 1999. na 32\% Ž i $46 \%$ M) uz porast odgovora kako je to podjednako primjereno zanimanje za oba spola (68\% M i 54\% Ž); ipak, i danas jedna trećina muških ispitanika pristaje uz odgovor da se radi o "ženskom” zanimanju, dok kod studentica čak polovica njih i danas to vidi ženskim zanimanjem (s 93\% 1999. na 46\%). I administrativni i tajnički poslovi doživjeli su istu "sudbinu" - od dominantno ženskih u 1999. godini sada su postali zajedničkima ( $88 \%$ M i 74\% Ž). Direktorski i menadžerski poslovi, jednako kao i zanimanja vezana uz sudstvo i politiku, kao izrazito statusno naglašena, u međuvremenu su od dominantno muških zanimanja u 1999. godini postali uglavnom zajedničkima. Što se direktorskih tiče, to danas misli $82 \%$ studenata i $70 \%$ studentica; međutim, i danas gotovo trećina studentica vidi te poslove kao tipično "muško" zanimanje, za razliku od petine studenata. Isti trend bilježimo i kod sudstva koje je također od tipičnog "muškog" zanimanja 1999., uz što je pristajao 
Grafikon 1. Percepcija zanimanja političara/ki

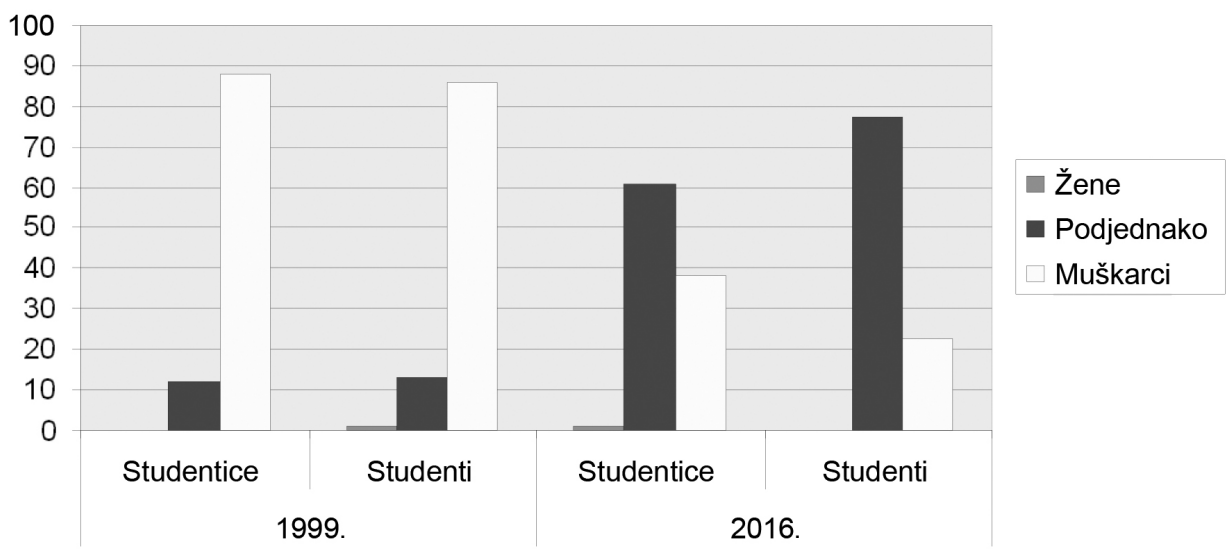

svaki drugi ispitanik, danas percipirano kao zanimanje kojim se bave i žene i muškarci podjednako ( $85 \%$ M i 78\% Ž). Što se tiče politike, također "muškog” zanimanja 1999. godine (86\% M i 88\% Ž), percepcija danas tendira k zanimanju podjednako prihvatljivom za oba spola (78\% M i 61\% Ž); ipak, još uvijek su značajni postoci prema kojima je to i dalje "muško" zanimanje (38\% Ž i 22\% M), uz izraženu razliku u percepciji studentica i studenata.

Za razliku od toga, IT sektor, koji nije bio uključen u listu zanimanja 1999. godine, pokazuje kako ga ispitanici percipiraju podjednako primjerenim za oba spola (62\% M i 47\% Ž), uz osjetnu međuspolnu razliku; tako ga "muškim" zanimanjem smatra svaka druga studentica (54\%) i čak svaki treći student (36,5\%). Medicina i znanost ostaju percipirani kao zanimanja primjerena za oba spola, ali uz porast intenziteta pristajanja uz taj odgovor do danas. Interesantno je da kod znanosti opredjeljenje za egalitarnost bilježi osjetan porast s 58\% M i 58\% Ž 1999. na 79\% M i $85 \%$ Ž.

Podaci istraživanja navode na zaključak kako je u proteklih sedamnaest godina percepcija o rodno specifičnim zanimanjima - tipičnim “ženskim” ili "muškim”, u potpunosti zamijenjena uvjerenjem da su danas sva spomenuta zanimanja podjednako primjerena za oba spola, dakle, egalitarna. Kod žena su dva tipična "ženska" zanimanja postala podjednako percipiranim za oba spola, a kod muškaraca su tri prestala biti "muškim" zanimanjima te postala zajedničkim. Ona koja su i ranije smatrana zajedničkim zanimanjima ostala su to do danas, uz porast broja odgovora. Konkretno, odgoj i obrazovanje te administrativni poslovi prestaju biti "ženska" zanimanja, a direktorski, menadžerski, sudbeni te oni vezani uz politiku prestaju 
biti “muška” zanimanja; zanimanja vezana uz medicinu, znanost i IT potvrđena su kao zajednička zanimanja za oba spola, ali uz ustaljenu razliku u percepciji studentica i studenata. Ima li ta razlika odraz i pri procjeni uloga žena i muškaraca "izvan doma"?

Danas briga oko zarade ostaje podjednakom zadaćom za oba spola, ali uz značajan pad broja takvih odgovora (s 84\% Ž i 63\% M 1999. na 50\% Ž i 56,5\% M) te uz porast odgovora da je riječ o "muškoj” zadaći (s 14\% Ž i 33\% M 1999. na 50\% Ž i 42\% M). Usavršavanje i napredovanje u profesiji danas se češće nego 1999. godine prepoznaje kao aktivnost u kojoj podjednako sudjeluju žene i muškarci (sa $60 \%$ Ž i 55\% M 1999. na 70\% Ž i 71\% M), dok je, analogno, ocjena da je riječ o "muškoj" aktivnosti doživjela pad - prisutna je danas tek kod svakog četvrtog ispitanika (26\% Ž i $25 \%$ M).

Politička aktivnost i nadalje ostaje "muška", ali su takva uvjerenja u padu (sa 73\% Ž i 73\% M 1999. na 53\% Ž i 45\% M); istodobno raste broj odgovora o podjednakom angažmanu žena i muškaraca, što češće zapažaju studenti negoli studentice (55\% M i 47\% Ž). Sportom se žene i muškarci bave podjednako, ali znatno učestalije nego 1999. godine (s 55\% Ž i 42\% M 1999. na 84\% Ž i 71\% M); dvostruko se smanjila percepcija kako su sport i rekreacija "muška" aktivnost. A kako studenti procjenjuju uloge žena i muškaraca u domu?

\section{Uloge žena i muškaraca "u domu”}

Kućanski poslovi i nadalje ostaju “ženski” (97\% M i 89\% Ž 1999. te 78\% M i 85\% Ž 2016.), ali uz smanjenje broja takvih odgovora, pogotovo studenata; prati ih porast opcije "podjednako", što brojnije vide studenti (s 3\% Ž i 9\% M 1999. na 15\% Ž i $22 \% \mathrm{M})$.

Podjednaka uključenost oba spola u brigu za djecu i njihov odgoj bilježi značajan pad (s 50\% Ž i 66\% M 1999. na 25\% Ž i 43,5\% M), uz porast odgovora da se radi o "ženskoj” zadaći (s 49\% Ž i 38\% M 1999. na 75\% Ž i 57\% M), što studentice percipiraju u znatno većoj mjeri nego studenti.

Odgovori potvrđuju da je odlazak dječjem liječniku i nadalje “ženska” zadaća, ali uz pad broja odgovora (sa 72\% Ž i 52\% M 1999. na 62\% Ž i 41\% M); raste broj onih koji to sve više prepoznaju podjednakom zadaćom za oba spola (s $26 \% \check{Z}$ i 42\% M 1999. na 38\% Ž i 59\% M), u čemu prednjače studenti. Isto je moguće zaključiti i kod odgovora o posjećivanju roditeljskih sastanaka, ali uz drugačiji trend kretanja: to je i dalje "ženska" zadaća, ali uz porast broja odgovora, posebice studentica (s 49\% Ž i 46\% M 1999. na 55\% Ž i 46\% M); da se radi o podjednakoj zadaći za oba spola danas misli više studenata nego studentica.

Briga za starije članove obitelji ostaje “ženska” zadaća, studentice tako odgovaraju brojnije nego prije (s 50\% Ž 1999. na 62\% Ž), ali ne i muški ispitanici - oni 
Grafikon 2. Percepcija o tome tko obavlja kućanske poslove

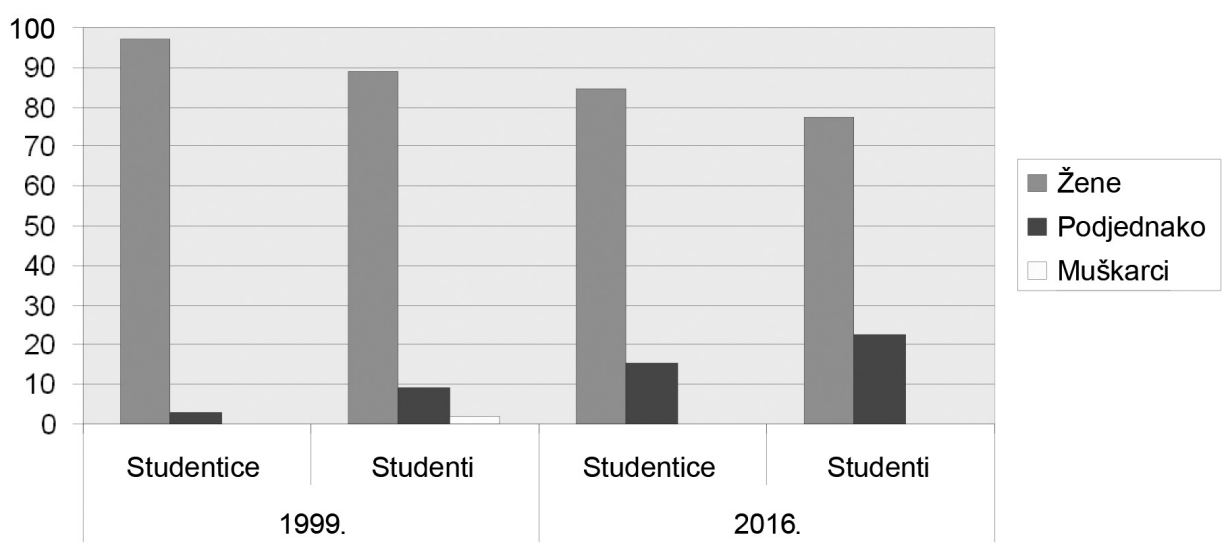

slično kao i ranije, u gotovo istom postotku (60\%), izjavljuju da je to podjednako zadaća i žena i muškaraca.

Međutim kod organiziranja obiteljskih proslava dolazi do značajne promjene - naglašenog porasta percepcije o podjednakoj ulozi žena i muškaraca (s 35\% Z̆ i $58 \%$ M 1999. na $82 \%$ Ž i $83,5 \%$ M), uz pad broja odgovora da je to dominantno “ženina” zadaća, u čemu se slažu oba spola (sa 62\% Ž i 31\% M 1999. na 17\% Ž i $15 \% \mathrm{M})$.

U domu kućanski poslovi, odlazak dječjem liječniku i na roditeljske sastanke te briga za starije članove obitelji nisu postali egalitarnijima već ostaju tipičnim "ženskim" obiteljskim zadaćama do danas, pri čemu neke od njih - odlazak liječni$\mathrm{ku}$, odlazak na roditeljske sastanke, briga za starije te odgoj djece - pokazuju tendenciju porasta uključenosti žena u odnosu na ranije istraživanje. Kućanski poslovi ostaju i nadalje dominantno "ženski”, iako bilježe vrlo skromne promjene u smislu porasta uključenosti muškaraca. Muškarci se manje brinu za djecu, ali više sudjeluju u organizaciji obiteljskih proslava (uloga koja se smanjuje ženama).

Izvan doma žene i muškarci podjednako se usavršavaju u struci, zarađuju, bave sportom i rekreacijom; interesantan je porast odgovora da su zarađivanje i financijski poslovi zadaća muškaraca - dakle, rastu očekivanja prema muškarcima izvan doma. ${ }^{3}$ Politička aktivnost ostaje još uvijek dominantno "muška" zadaća uz trend

3 “... Stoga je muškarac koji većim dijelom financira kućanstvo ostvario svoju rodnu ulogu, što djeluje na njegovu percepciju kvalitete partnerske veze" (Kamenov i Jugović, 2011: 37). 
porasta odgovora kako se ipak radi o zadaći u kojoj participiraju oba spola (dvostruko više negoli prije sedamnaest godina).

Moguće je zaključiti kako egalitarnost ženskih i muških uloga u društvu mladi općenito percipiraju u većoj mjeri "izvan obitelji”, dok u obitelji još uvijek dominiraju tipične "ženske", odnosno "muške" uloge. Tako studenti žene "vide" dominantnima u nizu rodno specifičnih uloga u obitelji, neke im i rastu, dok podjednako kao muškarci participiraju i u zadaćama izvan doma. Dakle, potvrđuju se nalazi o ukupnom porastu broja zadaća za žene. Muškarci se dosta skromno uključuju u kućanske poslove, češće organiziraju obiteljske proslave, ali su manje uključeni u odgoj i brigu za djecu te njegu starijih. Njihove su uloge i nadalje dominantno vezane uz djelovanje izvan doma.

Dok je ranije istraživanje ukazalo na dominaciju ženinih zadaća u domu uz postepene promjene u pravcu uključivanja muškaraca (olakšanje vezano uz odgoj djece), sadašnji nalazi govore da su te zadaće za žene i danas jednako prisutne, čak i u porastu (podjednaki angažman oba spola se ovdje smanjio gotovo dvostruko, što signalizira jačanje tradicionalnih zadaća žena i kumulaciju ukupnih). Pored toga, ispitanici "vide" da konkretne dužnosti žena u odnosu na djecu rastu - odlazak liječniku, na roditeljske sastanke, što je slično nekim od nalaza iz istraživanja (Kamenov i Jugović, 2011: 33). Uz takvu praksu postavlja se pitanje - ima li žena uopće slobodnog vremena, kako je ono strukturirano te kome je u životu lakše - ženama ili muškarcima?

Studenti odgovaraju kako žene općenito imaju malo slobodnog vremena, ali se taj broj smanjuje i različito ga procjenjuju studentice i studenti (sa 73\% Ž i 54\% M 1999. na $67 \%$ Ž i $16 \%$ M). Struktura slobodnog vremena žena nije se izmijenila: najčešće obavljaju kućanske poslove, ali uz pad broja takvih odgovora (s 43\% Ž i 41\% M 1999. na 38\% Ž i 39\% M); bave se djecom, ali manje nego ranije (s $41 \%$ Ž i $32 \%$ M 1999. na $28 \%$ Ž i $29 \%$ M); izrazito je porasla briga za osobni izgled, gotovo četverostruko (sa 7\% Ž i 14\% M 1999. na 26\% Ž i 25\% M), a s druge strane praćenje medija i usavršavanje u struci tek skromno rastu (s 1,5\% Ž i 2\% M 1999. na 3\% Ž i 2\% M). Ukratko, žene u slobodno vrijeme ostaju okrenute kući i djeci iako nešto manje nego prije, ali se sve više počinju baviti osobnim izgledom, što samo potvrđuje rađanje novih/starih stereotipa o ženi koja bez obzira na obitelj i zaradu mora izgledati lijepo. Dio je to i širih očekivanja današnjeg društva koje izgled, ljepotu i mladost smatra poželjnim karakteristikama i preduvjetom uspjeha pojedinca. Usavršavanje u struci i zabava, prema ovim podacima, ženama nisu prioriteti.

Redoslijed aktivnosti muškaraca u slobodno vrijeme ostaje nepromijenjen: bave se politikom (38\% Ž i 37\% M), sportom i rekreacijom (21\% Ž i 24\% M), zabavom (19\% Ž i 15\% M) te usavršavanjem u struci (15,5\% Ž i 12\% M); kućanske poslove i brigu za djecu ne prepoznaju ni ispitanici ni ispitanice. Promjene su vidljive 
u smanjenju vremena za sport i rekreaciju, gotovo dvostruko, porast usavršavanja u struci (s $0 \%$ Ž i $2 \%$ M 1999. na $16 \%$ Ž i 12\% M) te čitanje i praćenje TV-a (s 1\% oba spola 1999. na 5\% Ž i $12 \%$ M). Ukratko, u slobodno vrijeme muškarci se bave politikom više nego ranije, bave se sportom i rekreacijom, ali manje nego prije, opuštanje i zabava su ostali jednako prisutni, ali je poraslo vrijeme za usavršavanje. Muškarci svoje slobodno vrijeme uglavnom usmjeravaju na sebe i sadržaje izvan doma.

Sukladno tome, većina studenata i studentica zaključuje da je muškarcima u životu lakše i takvo je uvjerenje u porastu s obzirom na 1999. godinu (sa 65\% Ž i 29\% M 1999. na 72\% Ž i 53\% M), pri čemu to muškarci priznaju dvostruko brojnije nego ranije. Jačanje kompeticije u društvu te nedovoljan interes društva za organizaciju obiteljskog života dovode do toga da se obitelji snalaze tako što preraspodjeljuju zadaće u pravcu pojačanog angažmana žena u domu ("vraćaju” se spolno specifičnim ulogama), dok im istodobno rastu i uloge izvan doma; muškarci prvenstveno brinu o zadaćama izvan doma, koje im čak i rastu, pa tek potom onima u obitelji. O tome svjedoče i razlike u količini i strukturi slobodnog vremena žena i muškaraca: žene su u slobodno vrijeme okrenute obitelji i kućanskim poslovima, u izvjesnoj mjeri sebi, dok se muškarci pretežno usmjeravaju na zadaće koje im donose bolju informiranost i usavršavanje u profesiji; to kod žena dovodi do osjećaja preopterećenosti i teže životne pozicije, što priznaju čak i muškarci.

\section{Percepcija uloga majki i očeva studenata}

\section{Uloge majke i oca "izvan doma"}

Istraživanje iz 1999. pokazalo je da zaposlenost majki, zajedničko odlučivanje roditelja, obavljanje zadaća majke i oca u obitelji i izvan nje te način odgoja djece upućuju na moderniji karakter obitelji naših studenata. Što pokazuju sadašnji podaci? ${ }^{4}$

Zarađivanjem se i danas podjednako bave očevi i majke (43,5\% M i 59\% Ž), ali se uočava porast broja majki koje same zarađuju (sa 7\% M i 11\% Ž 1999. na $22 \% \mathrm{M}$ i 23\% Ž); istodobno očevi studentica danas rjeđe participiraju u zarađiva-

${ }^{4}$ Studenti imaju najčešće 22 godine, očevi im najčešće imaju završenu srednju školu (53\% M i $58 \%$ Ž), a kod studentica očevi čak tri puta češće imaju visoko obrazovanje nego kod studenata (7\% M i 21\% Ž); majke su također najčešće završile srednju školu, ali ponovno više majki studentica ima završen fakultet nego kod studenata; očevi su najčešće zaposleni i kod studenata i kod studentica (71\%), a njih dvadesetak posto je u mirovini; majke su zaposlene u sličnom broju (73\%), dok je broj nezaposlenih majki oko $17 \%$; studenti su najčešće običajni vjernici (42\% M i $52 \%$ Ž), studenti muškarci su u nešto većem broju ateisti od studentica (35\% M i 20\% Ž), dok su studentice brojnije među aktivnim vjernicima (22\% M i 28\% Ž); članstvo u političkim strankama je prava rijetkost: $80 \%$ studenata i $97 \%$ studentica nisu članovi niti jedne stranke, pri čemu muški ispitanici članstvo ipak potvrđuju osjetno češće (16\% M i 1\% Ž). Osobni standard procjenjuju slično: on je osrednji (65\% M i 68\% Ž) ili visok (26\% M i 29\% Ž). 
Grafikon 3. Percepcija političkih aktivnosti u obiteljima studenata

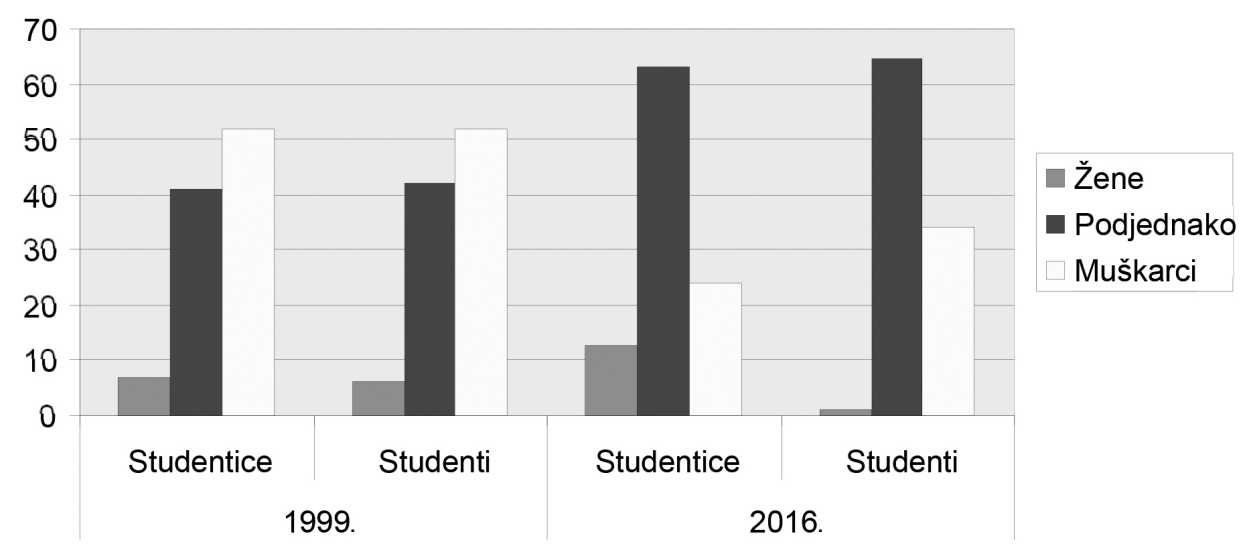

nju (s $29 \%$ 1999. na 18\%), dok studenti odgovaraju obrnuto - da raste uloga očeva u zarađivanju s $24 \%$ 1999. na $34 \%$. To svjedoči o prisutnoj razlici u percepciji studentica i studenata.

Usavršavanjem na poslu i napredovanjem i danas se, kao 1999. godine, najčešće okupiraju i otac i majka (47\% M i 59\% Ž), ali uz osjetan porast aktivnosti majke (s 13\% M i 17\% Ž 1999. na 33\% M i 21\% Ž).

Očevi su ranije bili dominantno povezani s politikom (42\% M i 41\% Ž 1999.), ali je do danas to postala aktivnost u kojoj brojnije i gotovo podjednako sudjeluju i očevi i majke ( $65 \% \mathrm{M}$ i $63 \%$ Ž); ipak, trećina studenata to još vidi muškom zadaćom u svojoj obitelji.

\section{Uloge majke i oca "u domu"}

U obiteljima studenata odgoj i briga oko djece ostaju do danas najčešće podjednako zadaćom i majke i oca (53\% M i 38\% Ž), što osjetno češće "vide" studenti muškarci; raste izjašnjavanje prema kojem to rade majke, što danas odgovara $41 \%$ studenata i $60 \%$ studentica; štoviše, u porastu je broj odgovora studentica koje svjedoče da je to isključivo majčina zadaća (s 35\% 1999. na 60\%). Slično, brigom za starije članove i danas se podjednako bave otac i majka (49\% M i 40\% Ž), ali uz pad broja takvih odgovora te, analogno, porast majčinog angažmana, što prvenstveno uočavaju studentice i to dvostruko brojnije negoli ranije (s 26\% 1999. na 58\%.)

Kod tipične "ženske" aktivnosti u 1999. godini, organiziranja obiteljskih proslava (55\% M i 34\% Ž), danas dolazimo do podjednakog angažmana oba roditelja $(66 \%$ M i $63 \%$ Ž). 
Grafikon 4. Percepcija o tome tko obavlja kućanske poslove u obiteljima studenata

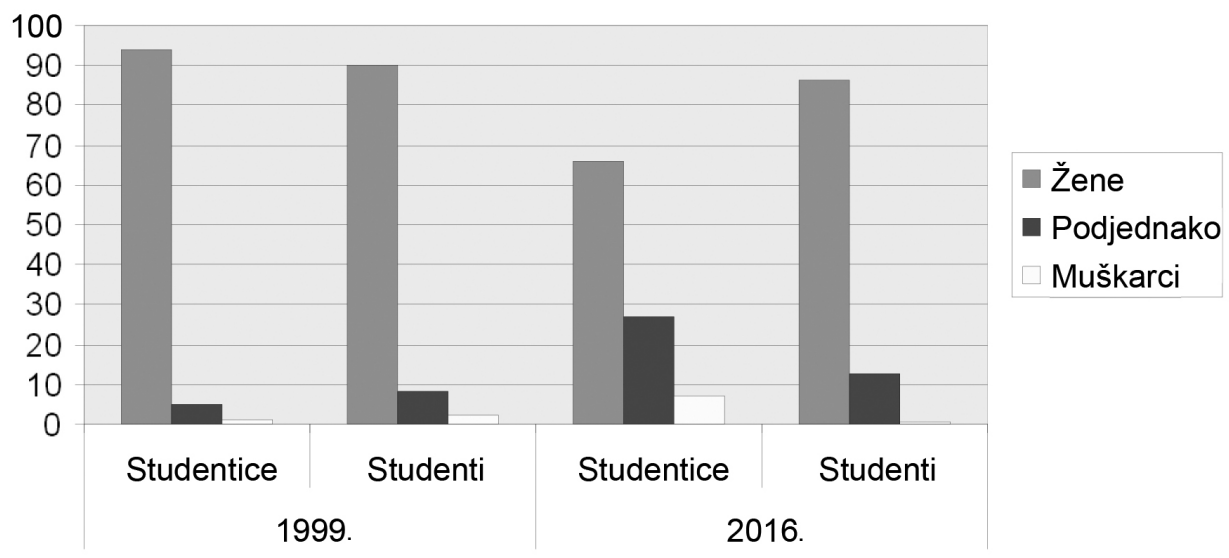

Tipična "ženska" zadaća iz 1999. godine, kućanski poslovi, ostaje i nadalje dominantno "ženska", ali smanjenog broja odgovora (s 94\% M i 90\% Ž 1999. na $66 \% \mathrm{M}$ i $86 \%$ Ž) i uz jasnu međuspolnu razliku u procjeni; u slabom je porastu odgovor prema kojem to danas podjednako obavljaju i očevi i majke (s 5\% M i $8 \%$ Z̆ 1999. na 27\% M i 13\% Ž), čemu se priklanja više studenata nego studentica.

Majke studenata uključenije ${ }^{5}$ su u sve nabrojene uloge izvan doma - zaradu, usavršavanje i bavljenje politikom - nego prije sedamnaest godina. S druge strane $u$ obitelji majkama raste broj zadaća, pa tako one dominiraju u brizi za starije, organizaciji obiteljskih druženja, kućanskim poslovima; pri odgoju i brizi za djecu očevi im postepeno sve više pomažu, iako je i ovdje u porastu percepcija da je to primarno zadaća majki. Sve to govori o karakteru obitelji u kojoj studenti žive, odnosno tipu socijalizacije. Utječe li do sada konstatirana opterećenost majki na tip odnosa pri odlučivanju u obitelji?

\section{Odnosi u obitelji te zadaće za djecu}

Uglavnom ne, ali i ovdje raste uloga majki. Odnosi među roditeljima ispitanika ostaju ravnopravni uz smanjenje broja takvih odgovora (sa 66\% M i 64\% Ž 1999. na $55 \% \mathrm{M}$ i $57 \%$ Ž); gotovo trostruko raste odgovor prema kojemu majka vodi glavnu riječ u obitelji (s 8\% M i 6\% Ž 1999. na 22\% M i 19\% Ž); raste broj ispitanika s jednim roditeljem - dvostruko više kod ispitanica.

5 I autorice Tomić-Koludrović i Kunac (2000) zaključuju da se žene zbog velikog rizika glede nezaposlenosti i niskog standarda "vraćaju" u obitelj kao "prisilne" povratnice, ali i "vladarice" u toj istoj obitelji, što će potvrditi i ovo istraživanje. 
Takva praksa u izvjesnoj mjeri utječe i na način uključivanja djece u obiteljske zadaće. Sadašnji podaci pokazuju isti redoslijed i sličan intenzitet kao ranije: studenti su najčešće obavljali "i muške i ženske" poslove podjednako (52\%), a zatim "muške" (27\%); studentice su najčešće obavljale "ženske" poslove (50\%), pa tek onda "i ženske i muške" (47\%); pokazuje se da ispitanici bez obzira na spol imaju danas u obitelji više dužnosti nego 1999. godine, pri čemu ispitanice imaju dvostruko više od ispitanika - odgovor "bez dužnosti" se smanjuje (s 11\% Ž i 15\% M na 3\% Ž i 7\% M).

Godine 1999. zaključili smo kako podaci upućuju na sliku bližu egalitarnoj raspodjeli uloga u obitelji, tipičnu za moderniju obitelj (Leinert Novosel, 1999: 65). Svoju su obitelj ispitanici opisali kao onu u kojoj roditelji ravnopravno donose odluke, dakle srazmjerno modernije orijentiranu, onu u kojoj ne postoje tipično "muški” i “ženski” poslovi za djecu, već tzv. "zajednički”. Danas situacija u selekcioniranoj populaciji pokazuje da iako roditelji odlučuju zajednički, postepeno raste broj majki koje "vode glavnu riječ" ili žive same s djecom, dok se analogno smanjuje broj očeva u toj ulozi; djeca najčešće u obitelji obavljaju podjednako i "muške" i "ženske" zadaće, što govori o modernijem karakteru obitelji, uz interesantan podatak o izvjesnom porastu opterećenosti djece većim brojem zadaća, pogotovo ženske djece. Dakle, majke, vjerojatno zbog povećanja broja svojih uloga i neadekvatne pomoći, više uključuju djecu u sve vrste poslova, pogotovo žensku, što može rezultirati prihvaćanjem modela "superžene" ili "žene žrtve" kod naših studenata. Vezano uz to može se pretpostaviti da će izlaz iz takve situacije mladi potražiti u pravcu redukcije i odgađanja osnivanja vlastite obitelji - rađanja manjeg broja djece, i to nakon što su osigurani egzistencija i profesionalni razvoj.

\section{Buduće obitelji studenata}

Kako bi temeljem gore navedenih podataka mogle izgledati obitelji ispitanika? Hoće li biti modernije ili tradicionalnog karaktera? O kakvoj će raspodjeli uloga biti riječ? U vlastitoj bi obitelji i danas najčešće željeli imati dvoje djece, ali je takvo opredjeljenje u odnosu na ranije u padu, pogotovo kod studentica (s 52\% Ž i 45\% M 1999. na 40\% Ž i 44\% M); interesantan je porast broja onih koji to još ne znaju (s 13\% Ž i 22\% M na 29\% Ž i 33\% M), što je više nego dvostruko brojniji odgovor u odnosu na 1999. godinu, posebice kod studentica. Veći broj djece u obitelji, troje i više, planira sve manje ispitanika.

I o načinu skrbi za djecu u vlastitoj obitelji više ispitanika nego ranije izjavljuje kako o tome još uopće ne razmišlja - svaka četvrta studentica (24\%) daje takav odgovor; druge danas preferiraju naizmjeničnu brigu majke i oca (41\%), zatim vrtić (31\%); studenti najčešće ne znaju (34\%), zatim navode vrtić (31\%), pa tek potom zajedničku skrb oca i majke (27\%). Ukratko, žene preferiraju partnerski odnos i za- 
jedničku brigu oko djece, a ispitanici organizirano čuvanje djece. Ima li to veze s njihovim profesionalnim planovima?

Budući da je otprije poznat nalaz prema kojemu briga za djecu umanjuje šanse za napredovanjem na radnom mjestu (Leinert Novosel, 1999: 105), zanimljivo je bilo pogledati sadašnje odgovore: većina ispitanika bez obzira na spol bezuvjetno bi podržala unapređenje svog partnera/partnerice na radnom mjestu ( $57 \%$ Ž i 59\% M), dok se podrška uz uvjet da ne strada obiteljski život do danas smanjila (sa 54\% M i 54\% Ž 1999. na 34\% Ž i 32\% M). Dakle, došlo je do promjene prioriteta kod oba spola.

S obzirom na te odgovore moguće je pretpostaviti kako će obitelji naših studenata biti modernijeg karaktera - bit će manje, o djeci će razmišljati sve kasnije; studentice će za razliku od studenata preferirati podjelu odgovornosti oba roditelja oko skrbi za buduću djecu, kako bi osigurale pretpostavke napredovanja u profesionalnom pogledu; studentima će profesionalni razvoj biti na prvom mjestu, a prednost pri čuvanju djece davat će organiziranim oblicima - vrtiću; važnost zaposlenja i napredovanja te pružanje bezuvjetne međusobne podrške prepoznata je kod većine studenata bez obzira na spol, što sve svjedoči o modernijem tipu obiteljskog života koji najčešće počiva na želji balansiranja između zaposlenja i obiteljskog života. U toj varijanti eventualni nedostatak partnerske pomoći pri obavljanju obiteljskih zadaća uz nejednaku količinu i strukturu slobodnog vremena otežavat će šanse žena u vezi sa zaposlenošću i napredovanjem, ili ih ponovno višestruko opteretiti po modelu "superžene" ili “žene žrtve", što kod muškaraca neće biti slučaj. Dakle, potvrđuje se da bez pomoći društva, poslodavca ili partnera žena ostaje višestruko opterećena, a muškarac "slobodan" za poslovnu karijeru.

Stoga i ne čudi nalaz prema kojemu studenti odgovaraju vrlo kritično o stanju u društvu - da danas vlast premalo brine o položaju žena u društvu izjavljuje $83 \%$ Z̆ i 56,5\% M, a kao glavnog "odgovornog" za takvo stanje sve brojniji studenti prepoznaju političke stranke (s $25 \%$ Ž i $19 \%$ M 1999 . na $44 \%$ Ž i $35,5 \%$ M), dok je važnost nevladinih udruga gotovo dvostruko smanjena (s 24\% Ž i 31\% M 1999. na $11 \%$ Ž i $15 \% \mathrm{M})$.

\section{Prognoza obiteljskih odnosa za dvadesetak godina}

Temeljem predviđanja studenata o njihovim vlastitim planovima zanimala nas je i općenita prognoza obiteljskih odnosa za dvadesetak godina. Već 1999. godine po mišljenju studenata i otac i majka u budućnosti trebaju podjednako preuzeti gotovo sve spomenute zadaće: zarađivanje, brigu oko djece, odlazak liječniku, usavršavanje u profesiji, bavljenje politikom. Nijedna aktivnost nije pokazivala statistički značajnu vezu sa spolom ispitanika. 
Grafikon 5. Percepcija o obavljanju kućanskih poslova za 20 godina

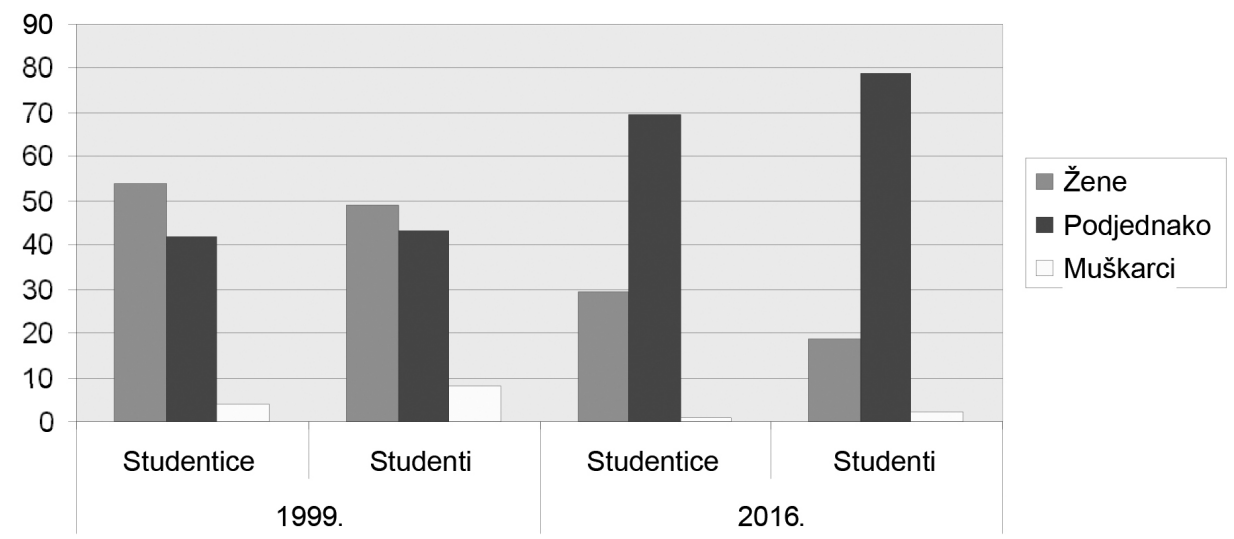

Danas je prognoza slična, uz neke promjene u intenzitetu odgovora. U obitelji će se roditelji najčešće podjednako brinuti za djecu, uz porast broja takvih odgovora (sa 75\% Ž i 73\% M 1999. na 77\% Ž i 82\% M), u što više vjeruju studenti muškarci; angažman majki "stagnira" u odnosu na ranije podatke (s 22\% $\check{Z}$ i 18\% M 1999. na $22 \%$ Ž i 16,5\% M). Kućanski poslovi bit će zajedničkima (70\% Ž i 79\% M); no i danas više ispitanica nego ispitanika (30\% Ž i 19\% M) očekuje da će ih i u budućnosti dominantno obavljati majke.

Izvan obitelji u budućnosti će se očevi i majke podjednako usavršavati u profesiji, što danas ispitanici procjenjuju u većem broju nego prije (s $81 \%$ Ž i $80 \%$ M 1999. na $87 \%$ Ž i M); u niskim postocima, ali dvostruko brojnije, muški ispitanici očekuju da će to biti zadaća očeva $(12 \% \mathrm{M}, 6 \%$ Ž).

I politika postaje podjednako aktivnost majki i očeva uz osjetni porast takvih odgovora (sa 71\% Ž i 58\% M 1999. na 91\% Ž i 79\% M) i veću zadršku studenata. Prema mišljenju ispitanika, roditelji će se za dvadesetak godina jednako brinuti oko zarade, kućanstva, odgoja djece, za njihovo školovanje i zdravlje, oko starijih članova, podjednako će se usavršavati u profesiji te baviti politikom. Ni kućanski poslovi neće biti više isključivo "ženski”, već zajednički, pri čemu su ispitanice opreznije u prognozi. Dakle nijedna aktivnost ne pokazuje značajniju vezu sa spolom. Čini se da se studentice i studenti u prognoziranju najčešće priklanjaju egalitarnim rješenjima - podjednakoj uključenosti majki i očeva, i to u većem broju negoli ranije. Potvrđuje se ideal obitelji utemeljene na egalitarnim odnosima, dakle modernijeg karaktera. 
Grafikon 6. Percepcija o političkim aktivnostima za 20 godina

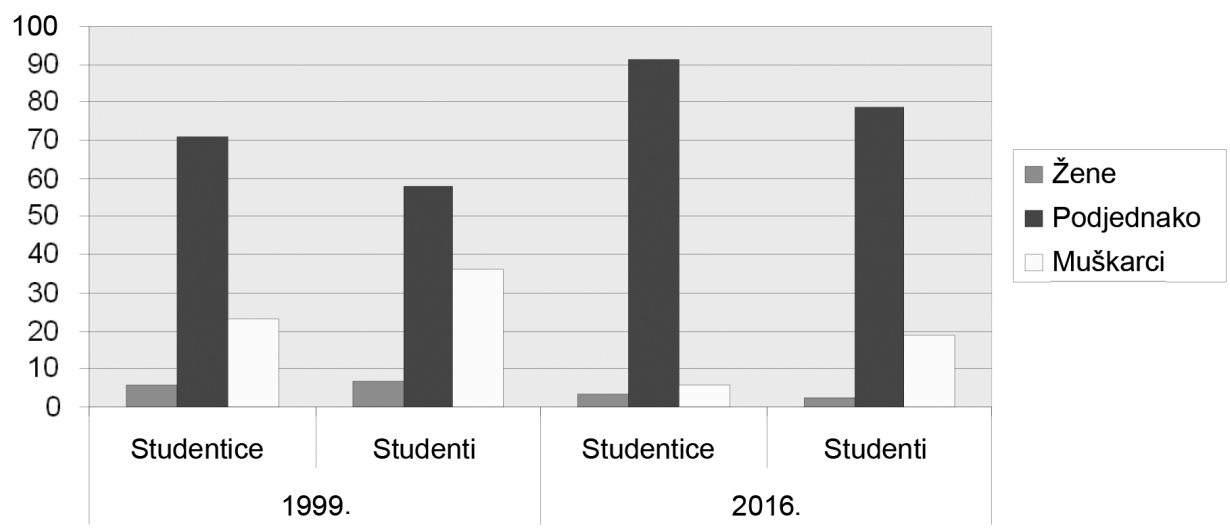

\section{Zaključak}

Na općoj razini društva mladi u 2016. godini percipiraju uloge žena i muškaraca u osjetno manjoj mjeri rodno specifičnima nego prije sedamnaest godina. To se prvenstveno odnosi na sferu "izvan doma", javnu sferu, u kojoj, kontrolirano kroz vrste zanimanja i karakter uloga, postoji visok stupanj egalitarnosti u participaciji žena i muškaraca. Poslovi vezani uz odgoj i obrazovanje, administrativni i tajnički poslovi prestaju biti “ženskima”, dok direktorski, menadžerski, sudbeni i vezani uz politiku više nisu tipična "muška" zanimanja; zanimanja vezana uz medicinu, znanost i IT potvrđena su kao zajednička za oba spola, ali uz ustaljenu razliku pri procjeni ispitanika oba spola. To potvrđuju i nalazi o podjednakoj uključenosti žena i muškaraca u obnašanje uloga u javnosti, odnosno "izvan doma" - usavršavanje u profesionalnom razvoju, podjednake uloge u zarađivanju, ali uz porast očekivanja od muškaraca, te bavljenje sportom i rekreacijom. Zanimanja vezana uz politiku, kao jedina iznimka, do daljnjega ostaju vezana uz muški spol, uz naglašeni porast procjene kako se ipak radi o zanimanjima primjerenim i ženama i muškarcima.

Sve to potvrđuje ranije nalaze koji su u vezi s istom temom upućivali da se promjene u odnosima lakše zbivaju u javnosti nego daleko od "očiju" te iste javnosti - u obitelji. Situacija je stoga osjetno drugačija u privatnoj sferi, "u domu”, o čemu svjedoče podaci o opterećenosti žena obiteljskim zadaćama: kućanski poslovi, briga za odgoj i zdravlje djece, odlasci liječniku i na roditeljske sastanke te briga oko starijih članova dominantno su ženine zadaće, pri čemu su neke od njih u porastu u odnosu na 1999. godinu. Dakle, žene se više nego ranije brinu oko odgoja djece, 
vode djecu liječniku, odlaze na roditeljske sastanke, brinu se za starije, dok im se u kućanskim poslovima tek postupno pridružuju i muškarci. Oni manje participiraju u aktivnostima oko djece, što im povećava šanse u vezi sa zaposlenošću i profesionalnim razvojem; u obitelji preuzimaju organizaciju obiteljskih proslava i druženja.

Dok je ranije istraživanje ukazivalo na dominaciju ženinih zadaća u domu, ali uz postepene promjene u pravcu smanjenja broja ženinih zadaća te uključivanje muškaraca (olakšanje vezano uz odgoj djece), sadašnji nalazi govore da su te zadaće za žene i danas jednako prisutne, neke čak i u porastu (opredjeljenje za podjednaku uključenost žena i muškaraca gotovo je dvostruko smanjeno, što signalizira jačanje tradicionalnih zadaća za žene i kumulaciju ukupnih). Ne čudi percepcija prema kojoj ženama nije nimalo lako u životu, o čemu svjedoči i način korištenja slobodnog vremena žena koje one uglavnom i dalje posvećuju obitelji, a tek ponešto brizi za sebe i svoj izgled. Muškarci sve do danas ostaju prvenstveno usmjereni na usavršavanje, informiranje, bavljenje politikom, dakle na aktivnosti "izvan doma".

Praksa u obiteljima studenata dodatno potvrđuje majčinu ulogu u zarađivanju, osobito tamo gdje žive same s djecom; majke se u sve većoj mjeri usavršavaju u profesionalnom pogledu, aktivnije su uključene u politička zbivanja negoli se općenito prepoznaje. Međutim, u domu im raste uloga i u kućanskim poslovima, u čemu se razilaze mišljenja studenata s obzirom na spol - studentice tako odgovaraju brojnije nego studenti, koji to najčešće procjenjuju zajedničkom zadaćom majki i očeva; majke dominantno skrbe za starije članove, dok im kod odgoja djece očevi više pomažu negoli se općenito percipira u društvu; pri organiziranju obiteljskih proslava danas je moguće u obitelji konstatirati zajednički angažman oba roditelja. Tipične su muške uloge nestale iz obitelji.

Godine 1999. zaključili smo kako podaci upućuju na promjene u ulogama u pravcu egalitarne raspodjele, karakteristično za moderniju obitelj (Leinert Novosel, 1999: 65). Svoju su obitelj studenti opisivali kao onu u kojoj roditelji ravnopravno odlučuju, dakle srazmjerno modernije orijentiranu, onu u kojoj ne postoje tipično "muški” i “ženski” poslovi za djecu, već tzv. zajednički. Današnji podaci ukazuju da i u selekcioniranoj populaciji nastupaju izvjesne promjene - iako roditelji i danas najčešće odlučuju zajednički, postepeno raste broj majki koje "vode glavnu riječ" ili žive same s djecom; djeca najčešće u obitelji obavljaju podjednako "i muške i ženske” zadaće, što govori o modernijem karakteru obitelji, uz interesantan podatak o izvjesnom porastu opterećenosti djece većim brojem zadaća, pogotovo ženske djece. Moguće je pretpostaviti da majke, vjerojatno zbog povećanja broja svojih obaveza i izostanka adekvatne pomoći, više uključuju djecu u sve vrste poslova, pogotovo žensku, što se može odraziti na tip organizacije života u budućim obiteljima studenata. 
S tim u vezi moguće je pretpostaviti da će izlaz iz takve situacije mladi potražiti u pravcu redukcije i odgađanja osnivanja vlastite obitelji dok ne osiguraju egzistenciju i ostvare planirani profesionalni razvoj. $\mathrm{O}$ tome svjedoče njihove izjave o budućim obiteljskim planovima, koje potvrđuju da će se odlučiti za obitelj modernijeg karaktera, manjeg broja djece, podjelu skrbi oko njih, ali nakon što ostvare ključnu pretpostavku - planirani profesionalni razvoj; to znači kasnije nego prije te uz bezuvjetnu partnersku podršku. Balansiranje između zaposlenosti, zarade, stručnog usavršavanja s jedne strane te želje za obiteljskim životom s druge značit će bez preraspodjele uloga u obitelji daljnje opterećenje žena, koje će "zasjeniti” njihovu mogućnost izbora; u svakom slučaju zahtijevat će, umjesto kumulacije ženskih zadaća - tradicionalnih rješenja, preraspodjelu i partnersku pomoć te veću brigu društva. U protivnom, profesionalne šanse žena bit će reducirane, a one će izlaz pronaći ili u odustajanju od planova, o čemu svjedoče podaci o depopulaciji u društvu, ili u daljnjoj kumulaciji uloga za žene, što kod muškaraca neće biti slučaj.

S druge strane, nalazi o "vraćanju" brojnih tradicionalnih zadaća ženama u obitelji, oni koji signaliziraju da je zarada ipak muška odgovornost, te tradicionalna struktura korištenja slobodnog vremena - žene "za obitelj”, a muškarci "za sebe" navode na oprez i konstataciju da mladi, pored opredjeljenja za modernije vrijednosti koje općenito zastupaju i planiraju, žive u realnosti u kojoj su ne samo prisutna već i jačaju (1999. - 2016.) tradicionalna rješenja vezana uz žene i muškarce. Taj se nalaz podudara s onime ranije spomenutog istraživanja o našem društvu kao umjereno tradicionalnom (Črpić, Bišćan i Aračić, 2005). Ostaje otvorenim pitanje je li to "klizanje" u pravcu tradicionalnih rješenja kod ove populacije posljedica porasta uvjerenja u tradicionalne vrijednosti ili nedostatka drugih oblika i načina organizacije obiteljskog života, dakle "tradicionalnost iz nužde"?

Mladi misle da se o tome u društvu nedovoljno brine te da samo kroz politi$\mathrm{ku}$, političke stranke, mogu očekivati promjene; uloga nevladinih udruga se danas osjetno rjeđe prepoznaje u tom pogledu.

Ideal mladih za dvadesetak godina jest potpuna egalitarnost uloga žena i muškaraca ne samo izvan doma već i u njemu, pri čemu su studentice opreznije u prognozi. Potvrđuje se prisutnost stalnog jaza između ideala i stvarnog života koji, bez šire uključenosti društva, ostaje nepremostiv i usmjeren na pojedince, o čemu danas svjedoče i brojni akutni problemi društva. 


\section{LITERATURA}

Črpić, Gordan, Bišćan, Željka, Aračić, Pero. 2005. Nove (i stare) uloge žena i muškaraca u suvremenoj Europi, u: Baloban, J. (ur.): U potrazi za identitetom. Golden marketing - Tehnička knjiga. Zagreb.

Galić, Branka. 2011. Društvena uvjetovanost rodne diskriminacije, u: Kamenov, Ž. i Galić, B. (ur.): Rodna ravnopravnost i diskriminacija u Hrvatskoj. Istraživanje "Percepcija, iskustva $i$ stavovi o rodnoj diskriminaciji u $R H$ ”. Ured za ravnopravnost spolova Vlade RH: 9-28.

Kamenov, Željka, Galić, Branka (ur.). 2011. Rodna ravnopravnost i diskriminacija u Hrvatskoj. Istraživanje "Percepcija, iskustva i stavovi o rodnoj diskriminaciji u RH". Ured za ravnopravnost spolova Vlade RH.

Kamenov, Željka, Jelić, Margareta, Tadinac, Meri, Hromatko, Ivana. 2007. Quality and stability of the relationships as a functions of distribution of housework, financial investments, and decision making between partners, u: Book of selected proceedings, 15th Psychology days in Zadar: 133-151.

Kamenov, Željka, Jugović, Ivana. 2011. Percepcija, iskustvo i stavovi o rodnoj (ne)ravnopravnosti u obitelji, u: Kamenov, Ž. i Galić, B. (ur.): Rodna ravnopravnost i diskriminacija u Hrvatskoj. Istraživanje "Percepcija, iskustva i stavovi o rodnoj diskriminaciji u RH”. Ured za ravnopravnost spolova Vlade RH: 28-38.

Leinert Novosel, Smiljana. 1999. Žena na pragu 21. stoljeća - između majčinstva i profesije. TOD i EDAC. Zagreb.

Leinert Novosel, Smiljana. 2003. Stavovi poslodavaca prema profesionalnoj i obiteljskoj angažiranosti žena. Državni zavod za zaštitu obitelji, materinstva i mladeži. Zagreb.

Leinert Novosel, Smiljana. 2011. Percepcija, iskustvo i stavovi o rodnoj (ne)ravnopravnosti u politici, u: Kamenov, Ž. i Galić, B. (ur.): Rodna ravnopravnost i diskriminacija u Hrvatskoj. Istraživanje "Percepcija, iskustva i stavovi o rodnoj diskriminaciji u RH". Ured za ravnopravnost spolova Vlade RH: 185-209.

Tomić-Koludrović, Inga. 2015. Pomak prema modernosti - Žene u Hrvatskoj u razdoblju zrele tranzicije. Jesenski i Turk. Zagreb.

Tomić-Koludrović, Inga, Kunac, Suzana. 2000. Rizici modernizacije: žene u Hrvatskoj devedesetih. Udruga građana "Stope nade". Split. 


\title{
Smiljana Leinert Novosel \\ SOCIAL STATUS OF WOMEN IN CROATIA: WOMAN AND FAMILY 1999-2016
}

\begin{abstract}
Summary
The conducted longitudinal research (1999-2016) about young, educated examinees' perception on changes in typical women and men roles showed a high degree of egalitarism in the Croatian public sphere, controlled by different kinds of profession and role characteristics. On the other hand, in the private sphere, it was shown that women today have an even more difficult role in the family than before - women again play their traditional roles, such as taking care of children and the elderly, taking them to doctors, taking part in parents' meetings in schools. Men tend to help them in their housework, but participate less in activities connected to children, their education and upbringing. This increases men's chance in employment and professional development. Consequently, women still dominantly spend their free time on family matters and taking care of their personal appearance, unlike men, who spend their free time mostly on themselves. Although typical modern family and egalitarian relations are still an ideal for the young, the practice is a bit different than in 1999. The continuation of cumulating roles for women, the modern and traditional ones, without redistribution, raises the question whether traditional understandings or "traditionalities of necessity" are strengthened in response to leaving the responsibility for organization of family life exclusively to individuals.
\end{abstract}

Keywords: Gender Equality, Students, Female and Male Roles, Family, Society

Prof. dr. sc. Smiljana Leinert Novosel redovita je profesorica u trajnom zvanju na Odsjeku za strateško komuniciranje na Fakultetu političkih znanosti u Zagrebu. Kontakt: Smiljana Leinert Novosel, Fakultet političkih znanosti, Sveučilište u Zagrebu, Lepušićeva 6, 10000 Zagreb. E-mail: smiljana.leinert-novosel@zg.t-com.hr 